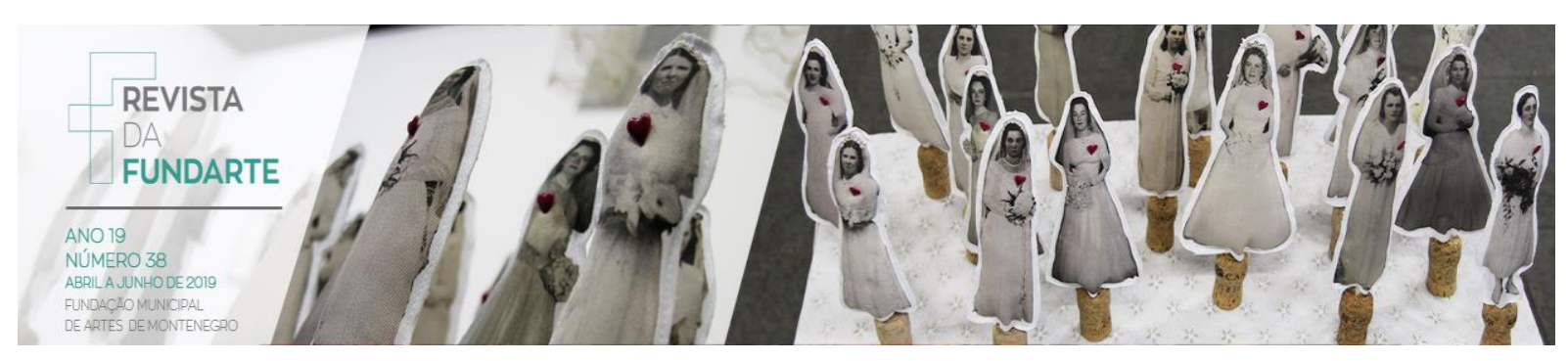

\title{
CORPOS BRINCANTES: O FOLCLORE COMO ESTRATÉGIA DE TRABALHO COM CRIANÇAS EM SITUAÇÃO DE VULNERABILIDADE E RISCO SOCIAL
}

Rejanete Vieira ${ }^{1}$

Resumo: O presente estudo se propôs a investigar como o trabalho corporal desenvolvido por meio das brincadeiras folclóricas contribui para o processo de socialização de crianças em vulnerabilidade e risco social. Neste âmbito, a pesquisa direcionou-se no sentido de identificar a colaboração das relações corpóreas expressas na atuação da brincadeira folclórica de forma que possa interferir, promover e estreitar possibilidades na constituição dessa socialização. A pesquisa, compreendida entre os meses de outubro e dezembro do ano de 2013, ocorreu através da atuação com a Oficina de Folclore, ação do Projeto de Extensão Núcleo de Folclore da UFPel.

Palavras-chave: Folclore; Brincadeira; Corpo.

\section{BRINCANTES BODIES: THE FOLKLORE AS A STRATEGY OF WORKING WITH CHILDREN IN SITUATION OF VULNERABILITY AND SOCIAL RISK}

\begin{abstract}
This study aimed to investigate how the body work through folk games contributes to the socialization process of children at vulnerability and social risk. In this context, the research is directed towards identifying the collaboration of body relationships expressed in the performance of folk play so that it can interfere, promote and narrowing possibilities in constitution of this socialization. The research, between the months of October and December of the year 2013, occurred through the action with the Office of Folklore, action of "Projeto de Extensão Oficina do Folclore da Universidade Federal de Pelotas" - Extension Project Core Folklore at Federal University of Pelotas.
\end{abstract}

Keywords: Folklore; Play; Body.

O corpo humano é objeto de estudo e de interferência de diversas áreas do conhecimento. Nos últimos séculos, diferentes vertentes e concepções se fundamentaram no pensamento dualista desenvolvido pelo filósofo francês René Descartes, cuja concepção dicotômica do sujeito vem desembocar no modo como pensamos a ideia de divisão do sujeito até hoje.

O entendimento do dualismo proposto por este filósofo influenciou sobremaneira, e durante muito tempo, as formas de compreensão do sujeito a partir da ideia de mente e de corpo separadamente. Embora se considere que o sujeito é

\footnotetext{
1 Graduada em Dança - Licenciatura pela Universidade Federal de Pelotas (2014). Tem experiência na área de Artes, com ênfase em Dança. Aluna regular no Curso de Pós-Graduação Lato Sensu em Educação - Instituto Federal de Educação, Ciência e Tecnologia - IFSul - Pelotas, ingresso 2017/2.
}

VIEIRA, Rejanete. Corpos brincantes: o folclore como estratégia de trabalho com crianças em situação de vulnerabilidade e risco social. Revista da FUNDARTE, Montenegro, p.12-32, ano 19, no 38, abril/junho de 2019.

Disponível em: http://.seer.fundarte.rs.gov.br/index.php/RevistadaFundarte/index> 28 de junho de 2019. 


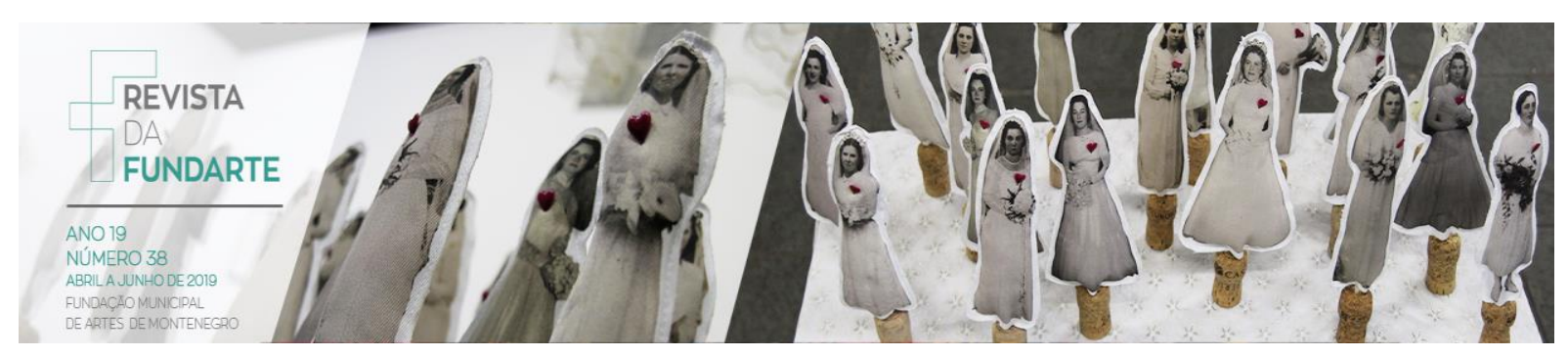

uma totalidade, o pensamento ocidental está impregnado de concepções dualistas, sendo que muitas delas são produtos do pensamento cartesiano, que dividem o sujeito em um extrato mental, racional, e outro extrato físico, corpóreo, colocando ambos em uma posição dividida, supondo um conflito entre um e outros campos. Miranda (2008, p. 11) reforça este ponto de vista afirmando que, até pouco tempo, o entendimento acerca do corpo era o de que "habitávamos o nosso corpo e atuávamos no espaço", o que deflagra uma concepção claramente cartesiana.

Nos anos da década de 1960, o homem ocidental descobriu-se enquanto corpo, demarcando um fator de individuação que é assinalado por Le Breton:

Em nossas sociedades ocidentais, o corpo é, portanto, o signo do indivíduo, - lugar de sua diferença, de sua distinção; e, ao mesmo tempo, paradoxalmente, está frequentemente dissociado dele, devido à herança dualista que pesa sempre sobre sua caracterização ocidental. (2012, p.11).

O mesmo autor (2012, p. 7) depõe que o corpo se configura em um tema favorável para as pesquisas antropológicas, no sentido de que é a ele concedida a origem identificadora do homem. O autor afirma que: "A existência do homem é corporal". Em sua obra "Antropologia do Corpo e Modernidade", Le Breton define que cada sociedade, de acordo com sua visão de mundo, descreve um conhecimento particular sobre o corpo, conferindo-Ihe particular sentido e valor.

Diante disso, o presente trabalho se propõe a refletir acerca do entendimento corporal dos sujeitos desta pesquisa, os quais se encontram imersos num contexto institucional que, de certa forma, nega a condição de subjetividade inerente a cada um. Cabe assim indagar: como um indivíduo que está privado de seu ambiente elementar, a família, poderá se constituir integralmente (ou seja, inclusive corporalmente) e perceber-se socialmente inserido de acordo com as definições e os valores estabelecidos pela sociedade em que atua?

Conforme Gonçalves (1994, p. 13), o entendimento de que o homem é socialmente influenciado pelo contexto onde vive e que esta influência age diretamente nas relações corporais, altera a compreensão de sujeito-corpo e suas expressões na sociedade contemporânea. Nesta perspectiva, o presente trabalho se

VIEIRA, Rejanete. Corpos brincantes: o folclore como estratégia de trabalho com crianças em situação de vulnerabilidade e risco social. Revista da FUNDARTE, Montenegro, p.12-32, ano 19, no 38, abril/junho de 2019.

Disponível em: http://.seer.fundarte.rs.gov.br/index.php/RevistadaFundarte/index> 28 de junho de 2019. 


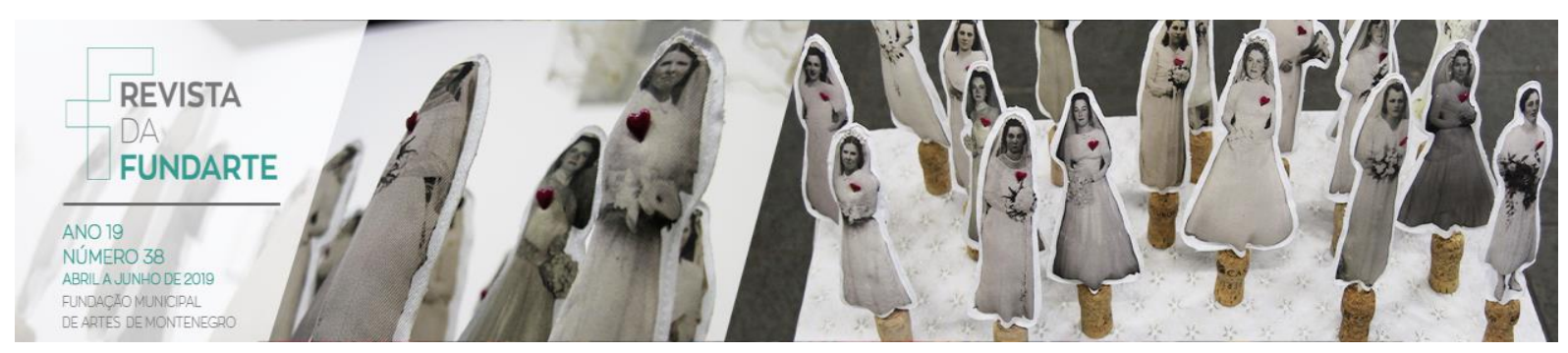

propõe a refletir sobre a condição que o corpo assume no contexto do Abrigo Institucional Casa Carinho, localizado na região central da cidade, mantido pela Prefeitura Municipal de Pelotas, se caracteriza pelo acolhimento de menores em situação de vulnerabilidade social e risco social, entendendo que a realização das atividades e a participação das crianças na Oficina de Folclore, através das brincadeiras, interferem nas relações corporais estabelecidas pelos sujeitos.

Estudos de História da Cultura e Antropologia Cultural, segundo Gonçalves (1994), apontam para uma probabilidade de que os indivíduos se utilizavam menos da comunicação gestual e mais da comunicação verbal durante o processo de desenvolvimento das atividades de sua vida social. Nas sociedades primitivas, o homem dependia mais da habilidade de seus movimentos e da agilidade de suas reações corporais, enquanto que na sociedade moderna a espontaneidade e expressividade corporal passaram a ser mais retraídas.

Ainda segundo esta autora, a relação do homem primitivo com a natureza, gerada por sua vida cotidiana e representada por suas atividades práticas nas condições de trabalho (caça, plantio e etc.), desdobrava-se na expressividade de seus movimentos: "[...] o homem primitivo revela sua íntima união com a natureza. Seu corpo, como parte da natureza, também produz ritmos, que se revelam na harmonia de seus movimentos corporais" (GONÇALVES, 1994, p. 15). Marques (2010a, p. 112) apoia a contextualização de Gonçalves (1994) quando afirma que: "o corpo, assim, como 'parte da natureza'2, é também a expressão "natural e espontânea" do ser humano, a manifestação de sua 'essência'".

Entende-se que o folclore é parte desta natureza social das culturas coletivas e que por meio da brincadeira folclórica, os movimentos surgidos nestes artefatos lúdicos podem representar a história das sociedades nas quais os sujeitos estão inseridos. Assim, cabe refletir acerca das expressões corporais surgidas no contexto do Abrigo no qual se desenvolveu o presente trabalho, entendendo que elas são representativas das vivências cotidianas e dos hábitos sociais que permeiam o dia-a-dia dos sujeitos naquele ambiente.

\footnotetext{
${ }^{2}$ Grifos da autora.
}

VIEIRA, Rejanete. Corpos brincantes: o folclore como estratégia de trabalho com crianças em situação de vulnerabilidade e risco social. Revista da FUNDARTE, Montenegro, p.12-32, ano 19, no 38, abril/junho de 2019.

Disponível em: http://.seer.fundarte.rs.gov.br/index.php/RevistadaFundarte/index> 28 de junho de 2019. 


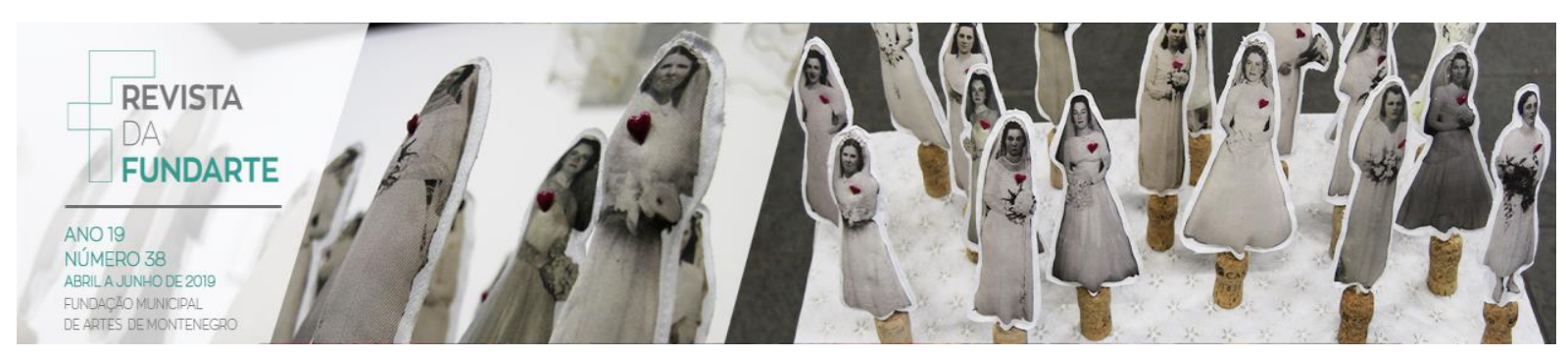

O apontamento trazido por Gonçalves (1994) destaca que o homem modifica e é modificado pela sociedade, no sentido de que o indivíduo vive em um determinado contexto social interagindo de forma dialética. Dessa forma, o contexto é transformado pelo sujeito, bem como o sujeito é transformado pela totalidade contextual a que pertence.

Diante disso, entende-se corpo como uma construção social, como um resultado do meio do contexto onde ele atua. Percebe-se que as relações entre os sujeitos interferem no conceito de corpo, e que estas relações corporais são indicadoras da construção de identidade.

Gonçalves (1994) coloca também que as posturas adotadas pelo homem ao lidar com sua corporeidade, bem como as maneiras de lidar com os princípios e influências do comportamento corporal não são universais e permanentes. Estas se caracterizam pelas intervenções que incidem no indivíduo ao longo de sua construção social, resultante de um processo histórico.

Neste sentido, interpreta-se que o ser humano tem uma identidade construída, também, a partir das relações corporais, sendo o corpo matéria-prima na construção dessa identidade. O estabelecimento da corporeidade no sujeito é atravessado constantemente pelos indicadores estruturados nos diferentes aspectos da cultura. Considerando o folclore enquanto cultura produzida e transformada pelo povo, aqui se salienta a importância do corpo como constituidor dessa cultura e, ainda de acordo com Gonçalves (1994), a cultura registra suas marcas nos sujeitos, compondo sua corporeidade e seu comportamento, influenciando os modos de sentir, pensar e agir.

Desta forma, a cultura assinala regras e estabelece ideais no que diz respeito às esferas afetivas, intelectuais, morais e físicas, ideais estes que podem representar, no que se refere à educação, aquilo que deve ser considerado no processo de socialização. Portanto, a importância do trabalho com o folclore, por meio da brincadeira folclórica, pode configurar interessante ferramenta para o desenvolvimento dos aspectos essenciais na constituição das relações humanas que compõe a formação socializadora do sujeito, um dos focos deste trabalho.

VIEIRA, Rejanete. Corpos brincantes: o folclore como estratégia de trabalho com crianças em situação de vulnerabilidade e risco social. Revista da FUNDARTE, Montenegro, p.12-32, ano 19, no 38, abril/junho de 2019.

Disponível em: http://.seer.fundarte.rs.gov.br/index.php/RevistadaFundarte/index> 28 de junho de 2019. 


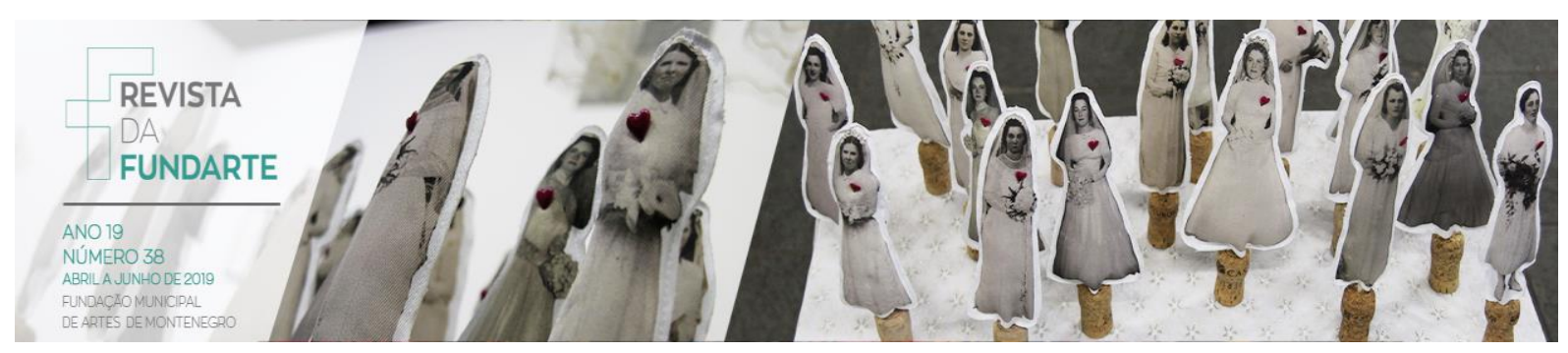

Os movimentos corporais sempre estiveram presentes na formação da história humana, configurando uma primordial interpretação cultural e social do sujeito. Neste sentido, Marques (2010a, p. 107) destaca que a história de cada sujeito não configura uma história singular. A autora afirma que as experiências que constituem a história formadora de cada indivíduo, são experiências influenciadas pelos aspectos sócio-culturais.

Tomando-se por base esta reflexão, melhor compreende-se o contexto de ocorrência do presente trabalho, considerando que cada sujeito traz a sua história, e que esta história o constrói corporalmente. Sabendo-se que durante a infância as brincadeiras fazem parte do cotidiano dos sujeitos, isto significa que o corpo, nesta fase, é muito constituído a partir da corporeidade nas brincadeiras, as atividades desenvolvidas a partir desta prática, podem contribuir para a construção corporal desses sujeitos.

Nesta perspectiva, Gonçalves reforça a ideia de Marques (2010a), assinalando que a condição de corpo de cada sujeito pertencente a determinado grupo cultural, revela suas peculiaridades, reforçando as características de tudo aquilo que diferencia tal grupo. A história da sociedade que exprime valores, leis, crenças e sentimentos e são o fundamento da vida social, é expressa através do corpo, por meio das relações que este corpo traça com um determinado contexto social (GONÇALVES, 1994, p. 14).

Portanto, trabalhar com as brincadeiras folclóricas significa estar trabalhando a história individual e coletiva dos sujeitos, visto que o corpo está no centro da ação individual e coletiva. Coletiva na perspectiva da história da sociedade, pois as vivências que distinguem os sujeitos, falam do homem e das transformações que seus modos de existência conhecem. Considera-se assim, se este sujeito brinca, se brincou ou se brincava, e como isto ocorria; e, ao mesmo tempo, oferece às brincadeiras o caráter individual, concebendo que a brincadeira é daquele sujeito, naquele lugar, naquele dia.

Trabalhar com o folclore, com as brincadeiras folclóricas como via de acesso para a construção de um processo em dança, apresenta diferença de um

VIEIRA, Rejanete. Corpos brincantes: o folclore como estratégia de trabalho com crianças em situação de vulnerabilidade e risco social. Revista da FUNDARTE, Montenegro, p.12-32, ano 19, no 38, abril/junho de 2019.

Disponível em: http://.seer.fundarte.rs.gov.br/index.php/RevistadaFundarte/index> 28 de junho de 2019. 


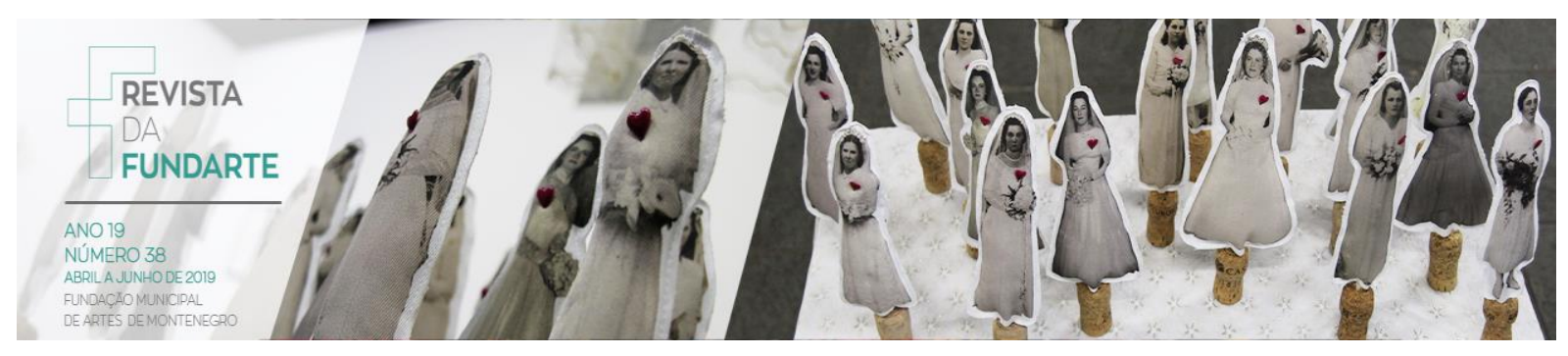

trabalho de dança contemporânea ou de dança clássica por exemplo. Visto que a ideia da corporeidade expressa nessas danças já traz uma série de significados que foram construídos sócio-historicamente e que foram passados de geração em geração. Contudo, existe abertura para novas possibilidades de criar utilizando-se dessa ação individual e coletiva.

As brincadeiras folclóricas, diferente de outras brincadeiras, como os jogos de computador, os quais igualmente são uma brincadeira, quase que necessariamente sugerem o movimento, o corpo como este lugar de construção dessa interação, torna-se imprescindível. No sentido de que se exige nessa corporeidade física, sócio-histórica uma complexidade mais ampla de movimentos, do que provavelmente estar sentado na frente do computador jogando.

Através da brincadeira acontece o toque, o qual favorece o contato, e este aproxima os sujeitos. $O$ corpo pode ser entendido como um território e existem fronteiras que permeiam estes territórios. Estas fronteiras delimitam o limite de onde um possa ultrapassar para alcançar o outro; e, ao mesmo tempo, este território diz do lugar que o indivíduo ocupa no mundo. $O$ valor que este sente que tem no mundo é demarcado a partir do corpo.

As performances particulares dos sujeitos denotam este valor que lhes é dado no mundo, ao observar se um indivíduo é mais fechado ou mais expansivo que outro, se acontece o toque em seu próprio corpo, ou ainda, se o corpo do outro é tocado, se este indivíduo se permite sentar no chão, ou seja, os modos de apropriação do mundo passam pela corporeidade.

Nesta perspectiva, Marques (2010b, p. 27) se utiliza da expressão freireana 'impregnar de sentidos'3 para relativizar acerca das relações cotidianas vividas em sociedade pelos sujeitos, as quais constituem a visão de mundo citada por Le Breton (2012).

Para contextualizar a expressão, Marques acessa o que seria o seu entendimento de sentido e impregnação:

\footnotetext{
${ }^{3}$ Grifo da autora.
}

VIEIRA, Rejanete. Corpos brincantes: o folclore como estratégia de trabalho com crianças em situação de vulnerabilidade e risco social. Revista da FUNDARTE, Montenegro, p.12-32, ano 19, no 38, abril/junho de 2019.

Disponível em: http://.seer.fundarte.rs.gov.br/index.php/RevistadaFundarte/index> 28 de junho de 2019. 


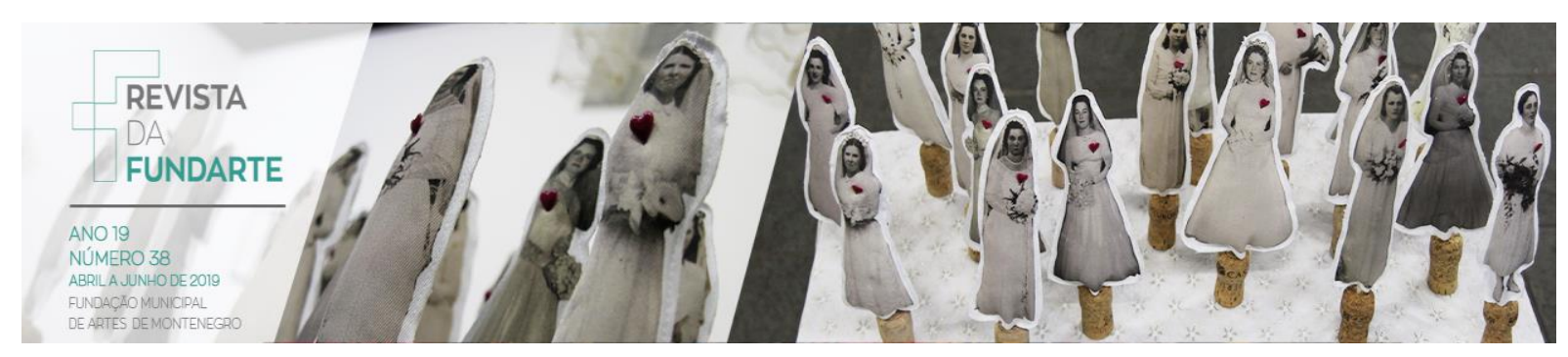

O sentido só se configura nas teias trançadas pelas relações sociais, pelos atos políticos, pelas produções e vivencias culturais. São teias de relações que constroem sentidos, que "impregnam de sentidos cada ato cotidiano. [...] A impregnação acontece à medida que nos relacionamos de forma crítica com os outros, com os objetos e com o meio nas tramas sociais .(2010b, p.28).

Por este ponto de vista, se pode assinalar que a socialização possivelmente ocorra no momento em que "impregnamos de sentido" nossas histórias. Isto acontece, quando estabelecemos integrações "[...] entre nossos pensamentos, sensações, afetos, emoções, atitudes, desejos, sonhos e também os pensamentos, sensações, afetos, emoções, desejos, sonhos dos outros [...]" (MARQUES 2010b, p. 28).

A comunicação dessa partilha nas relações pode ser ofertada a partir do desenvolvimento da brincadeira folclórica, disponibilizando o corpo dos sujeitos para que, através do toque e do contato sejam traçadas as teias que permitirão a consolidação das relações sociais.

Em um contexto de vulnerabilidade e risco social pondera-se que este impregnar de sentidos, apontado por Marques (2010b), possa estar prejudicado, debilitando a ocorrência das relações por meio do corpo. Segundo Padoin e Virgolin a vulnerabilidade social se origina na área dos Direitos Humanos e se configura pela caracterização de "[...] grupos ou indivíduos fragilizados, jurídica ou politicamente, na promoção, proteção ou garantia do seu direito à cidadania" (2010).

O risco é uma variável que aumenta a probabilidade de o indivíduo adquirir determinada doença quando exposto a ela (SAPIENZA; PEDROMÔNICO, 2005). A partir da década de 1980 o termo risco foi associado aos estudos sobre desenvolvimento humano, definindo e identificando aspectos e fatores que podem classificar determinado indivíduo em situação de vulnerabilidade e risco social. Associam-se essas particularidades no sentido de que nem todo sujeito que se encontra em vulnerabilidade social esteja em eminente risco social, pois um não exclui ou agrega o outro.

VIEIRA, Rejanete. Corpos brincantes: o folclore como estratégia de trabalho com crianças em situação de vulnerabilidade e risco social. Revista da FUNDARTE, Montenegro, p.12-32, ano 19, no 38, abril/junho de 2019.

Disponível em: http://.seer.fundarte.rs.gov.br/index.php/RevistadaFundarte/index> 28 de junho de 2019. 


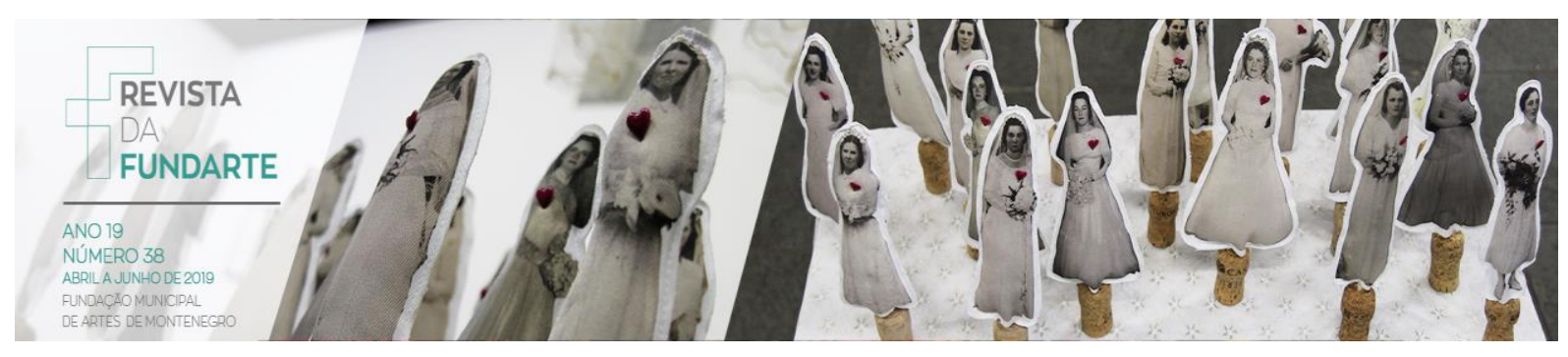

Dentre os fatores de risco ou as adversidades que os definem e os identificam, a fim de avaliar sua influência no desenvolvimento de crianças e adolescentes, a resiliência (capacidade que tem uma pessoa ou um grupo de se recuperar perante a adversidade e ultrapassá-la para continuar a seguir com a sua vida), se torna preponderante para que esses indivíduos identifiquem aporte em algumas das inúmeras possibilidades cotidianas, que Ihes permita traçar uma perspectiva.

De acordo com Padoin e Virgolin (2010), três categorias podem ser adotadas como embasamento para analisar a situação de vulnerabilidade social: os ativos, que configuram trabalho, educação, lazer e cultura; o conjunto de oportunidades procedentes do âmbito social, que são as oportunidades outorgadas pelo mercado, Estado e sociedade; e, por fim, mas não menos importante, as estratégias, que são as formas como os sujeitos articulam e utilizam os ativos de maneira a se confrontar com o contexto social onde está inserido.

Alguns aspectos dos fatores cognitivo, biológico ou sensório, suas carências ou apresentações, também podem ser considerados de risco, como prematuridade, desnutrição, baixo peso, lesões cerebrais, atraso no desenvolvimento, família desestruturada, minoria social, desemprego, pobreza, dificuldade de acesso à saúde e educação. Portanto, as variáveis que podem ser consideradas iminência de risco na infância e na adolescência, configuram síndrome pós-trauma, depressão, ansiedade, estresse, distúrbios de conduta ou de personalidade, evasão escolar, gestação precoce, problemas de aprendizagem, uso de drogas, violência familiar, desagregação familiar, violência física, abandono, maus-tratos (SAPIENZA; PEDROMÔNICO, 2005).

\section{Sobre a noção de folclore}

Antes de ser gerada a palavra folclore, já havia a existência de estudos a respeito dos conhecimentos do povo, um dos modos de se referir a este tipo de conhecimento é como tradições populares. Edelweiss (1979, p.19) afirma que os

VIEIRA, Rejanete. Corpos brincantes: o folclore como estratégia de trabalho com crianças em situação de vulnerabilidade e risco social. Revista da FUNDARTE, Montenegro, p.12-32, ano 19, no 38, abril/junho de 2019.

Disponível em: http://.seer.fundarte.rs.gov.br/index.php/RevistadaFundarte/index> 28 de junho de 2019. 


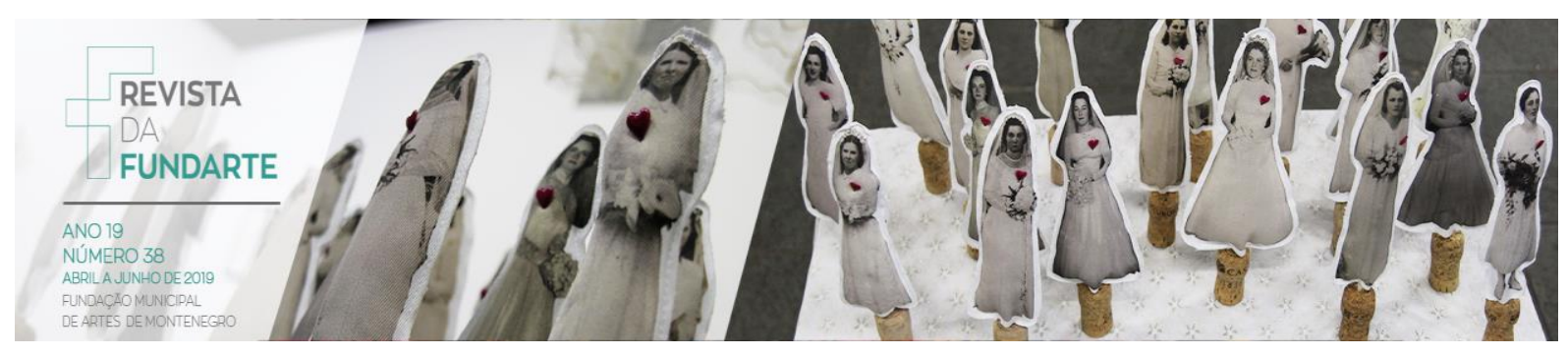

contos de fadas e as lendas, foram as primeiras considerações feitas por pesquisadores, em meados do século XIX, acerca dos estudos, na época, nomeados por tradições populares.

A partir dos registros dos irmãos Grimm (CABRAL, 1978, p.21) as superstições, os costumes, a música, as danças, o artesanato, a culinária, começaram a constituir a cultura popular, entendendo-se cultura pela intervenção humana associada a todo saber e fazer do sujeito. No entanto, somente após o termo folklore ter sido cunhado pelo arqueólogo inglês William John Thoms (18031885), em 1846 (VAN GENNEP, 1950, p.15) esses aspectos da cultura popular começaram a serem sistematizados, bem como começaram as definições de suas fronteiras.

Ainda de acordo com Edelweiss (1979, p.17), tais fronteiras começaram a ser traçadas levando-se em consideração alguns aspectos que poderiam delimitar o que vem a ser culto em contraposição com as coisas ditas populares, dentre eles estão a linguagem, o direito, a moral, as crenças religiosas, a literatura e a arte. "Entretanto, por mais que falemos em popular e culto, é impossível definir os limites exatos de cada qual" (EDELWEISS, 1979, p.18).

Van Gennep (1950, p.15) esclarece o significado de folklore (folk, povo e lore, conhecimento) palavra de origem anglo-saxônica, inicialmente grafada folk-lore; portanto, entende-se que folclore é o conhecimento que vem do povo, o estudo gerado a partir dos fatos histórico-culturais advindos de uma comunidade específica, de uma região própria.

É possível identificar como fato folclórico todo conhecimento que é percorrido de geração em geração, através do anonimato, com aprendizado natural. (EDELWEISS, 1979, p.22). Desse modo, se pode entender por folclore todo conhecimento apreendido pelos sujeitos, a partir do legado dos antigos como, lendas, contos, artesanato, música, culinária, festas populares, manifestações religiosas, ditos populares, linguagem, vestimentas, provérbios e brincadeiras, entre outras categorias aqui não especificadas (CARVALHO NETO, 1981).

VIEIRA, Rejanete. Corpos brincantes: o folclore como estratégia de trabalho com crianças em situação de vulnerabilidade e risco social. Revista da FUNDARTE, Montenegro, p.12-32, ano 19, no 38, abril/junho de 2019.

Disponível em: http://.seer.fundarte.rs.gov.br/index.php/RevistadaFundarte/index> 28 de junho de 2019. 


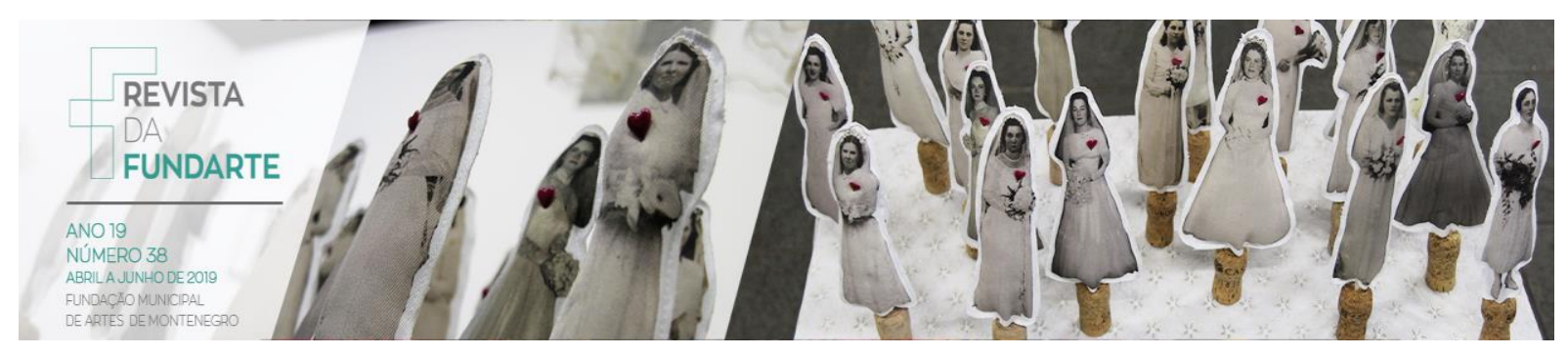

A conceituação de folclore se origina daquilo que é praticado, arquitetado, compartilhado de forma singela e da direta relação do sujeito com o fato. No Brasil, os primeiros estudos sobre folclore voltaram-se para a poesia, no entanto, Renato Almeida ${ }^{4}$, através de suas pesquisas, propõe uma aproximação com a Etnologia ou a Antropologia Cultural (FRADE, [s.d.]). O autor citado, sugere que os estudos não se restrinjam somente à literatura, mas que também, especule-se outros aspectos da vida social, se explore os materiais como artesanato, vestimentas, instrumentos musicais, além das danças e os elementos rituais, assim como se considere os fatores econômicos, políticos, históricos e regionais.

Segundo Fernandes (2003, p. 39), o folclore começou a ser reconhecido como forma de conhecimento científico, durante o século XIX, juntamente com 0 começo das pesquisas no que diz respeito aos elementos constituintes dessa ciência no Brasil. Neste período, o folclore enquanto conhecimento científico se propõe fundamentalmente a estabelecer a sabedoria característica do povo, através dos elementos materiais que constituem sua cultura. Deste modo, o folclore se propunha a estudar os modos de ser, de agir e de pensar característicos ao povo, tanto por meio de seus afazeres profissionais como o trabalho rural, o artesanato, a culinária, bem como através de fatos de natureza imaterial, ou seja, as lendas, os contos, as danças, os provérbios, as superstições.

Legitimando com a concepção de Fernandes, Marques (2010a) defende que a pesquisa a cerca dos elementos folclóricos a serem desenvolvidos na educação, deve ter como primeiro compromisso a fidelidade com a realidade do contexto, considerando as manifestações ali representadas. É indispensável se considerar que as relações traçadas entre uma manifestação e outra representam muito mais as experiências vividas pelos sujeitos, do que propriamente, as relações com as manifestações típicas de uma região. Ou seja, "[...] um jovem urbano está muito mais próximo de um jovem norte-americano, por meio do Hip-hop do que do jovem amazonense por intermédio do Carimbó” (MARQUES, 2010a, p.156).

\footnotetext{
${ }^{4}$ Biblioteca Virtual do Governo do Estado de São Paulo. Ver referências.

VIEIRA, Rejanete. Corpos brincantes: o folclore como estratégia de trabalho com crianças em situação de vulnerabilidade e risco social. Revista da FUNDARTE, Montenegro, p.12-32, ano 19, no 38, abril/junho de 2019.

Disponível em: http://.seer.fundarte.rs.gov.br/index.php/RevistadaFundarte/index> 28 de junho de 2019.
} 


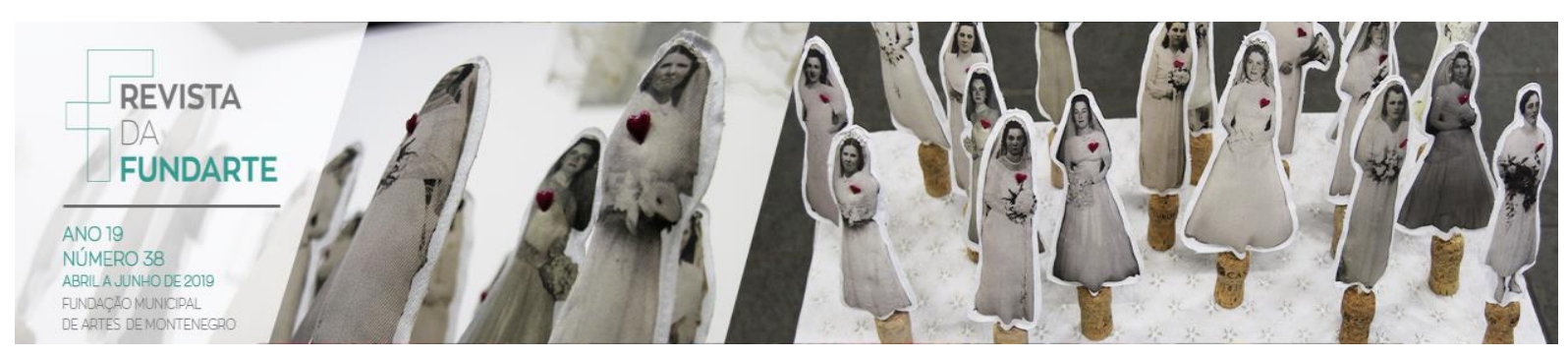

Considerando que a identidade brasileira está mais conectada ao conjunto de experiências dos sujeitos do que com a região onde eles vivem, Fernandes (2003) argumenta a relevância da influência do meio, pois os indivíduos não participam somente de um sistema de ideias, sentimentos e valores, estes agem e pensam em função destes princípios. A partir de uma perspectiva psicológica, etnológica e sociológica, segundo Fernandes (2003), estudiosos verificaram que o folclore não é efêmero, ele denota uma continuidade sociocultural, pois se a brincadeira de roda se faz presente nas atividades infantis até os dias de hoje, este brincar pode representar, para as crianças atuais, a preservação dos significados e a importância psicossocial que teve para as crianças de outrora.

É possível admitir a importância educativa do folclore considerando o plano das relações humanas, pois para realizar a brincadeira de roda, por exemplo, em seus formatos tradicionais, a criança precisa disponibilizar coletivamente seu comportamento, bem como ao efetuar os gestos usuais e as composições habituais que a envolvem. A criança entra em contato com um mundo simbólico, no qual estão mantidos aspectos da vida, sentimentos e valores, os quais proporcionam um ambiente ético que pode se perpetuar através do folclore.

De um lado, a criança aprende a agir como um "ser social": a cooperar e a competir com seus iguais, a se submeter e a valorizar as regras sociais existentes na herança cultural, a importância da liderança e da identificação com centros de interesses suprapessoais etc. De outro, introjeta em sua pessoa técnicas, conhecimentos e valores que se acham objetivados culturalmente. (FERNANDES, 2003, p 66).

Sob o ponto de vista de Carvalho Neto (1981), o folclore educacional pode ser explorado de duas maneiras, como informação e como formação, ou seja, podese simplesmente ilustrar os elementos do folclore e utilizá-los como fonte de dados, ou ainda ser estudado como disciplina que possibilite ao sujeito a constituição de sua personalidade. No entanto, defende que a adoção de um método não elimina a possibilidade de utilização do outro.

VIEIRA, Rejanete. Corpos brincantes: o folclore como estratégia de trabalho com crianças em situação de vulnerabilidade e risco social. Revista da FUNDARTE, Montenegro, p.12-32, ano 19, no 38, abril/junho de 2019.

Disponível em: http://.seer.fundarte.rs.gov.br/index.php/RevistadaFundarte/index> 28 de junho de 2019. 


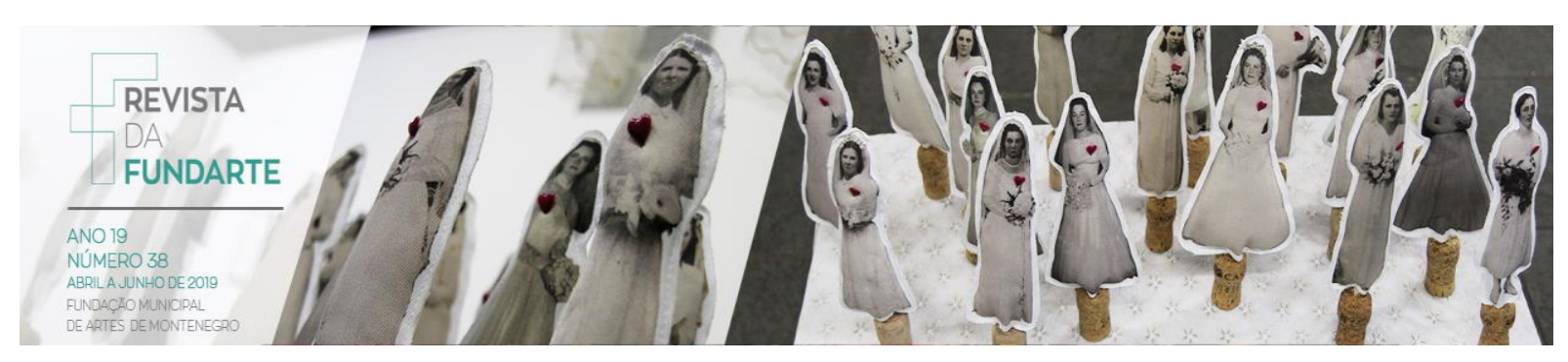

O objetivo do folclore como informação é a apresentação do fato pelo fato, é a informação utilizada como agregadora aos conhecimentos. Todavia, Carvalho Neto (1981, p. 07) sugere que ao trabalhar com crianças e adolescentes, assim como recomendam Marques (2010a) e Fernandes (2003), se deve proporcionar um conhecimento inerente à sua formação, tendo o cuidado de classificar o material a ser estudado de acordo com os objetivos específicos deste público.

\section{Brincadeira Folclórica}

O folclore está associado a diferentes tipos de conhecimento da cultura popular, as crenças praticadas pelo povo, sua culinária, sua vestimenta, seu artesanato, sua música, sua dança. No entanto isto não está associado somente com a produção de conhecimento que é feita pelos adultos e pelos mais velhos, entendendo que as crianças também são produtores de conhecimento e geracionalmente dentro das suas faixas etárias menores também desenvolvem hábitos que estão associados ao cotidiano desta determinada faixa etária. Dentro deste rol de conhecimentos do mundo da criança existe um conjunto de saberes e fazeres que constitui o que Inocente ([s.d.]) chama de folclore infantil. Por folclore infantil entende-se:

É o mundo folclórico da criança, seus brinquedos e brincadeiras, sua linguagem, canções, etc. Surgido pela necessidade de autopromover o seu lazer; seu desenvolvimento físico-intelectual. Pela necessidade de expressão, trocas afetivas e interação com o meio; e medir a sua capacidade e experiências. (INOCENTE [s.d.], p. 14).

O folclore infantil é expresso a partir de diferentes linguagens, uma destas linguagens manifesta-se através da brincadeira. Segundo Câmara Cascudo no Dicionário do Folclore Brasileiro a brincadeira é definida como "[...] sinônimos de jogos, rondas, divertimentos tradicionais infantis, cantados, declamados, ritmados ou não, de movimento, etc" (CÂMARA CASCUDO [s/d], p.170).

VIEIRA, Rejanete. Corpos brincantes: o folclore como estratégia de trabalho com crianças em situação de vulnerabilidade e risco social. Revista da FUNDARTE, Montenegro, p.12-32, ano 19, no 38, abril/junho de 2019.

Disponível em: http://.seer.fundarte.rs.gov.br/index.php/RevistadaFundarte/index> 28 de junho de 2019. 


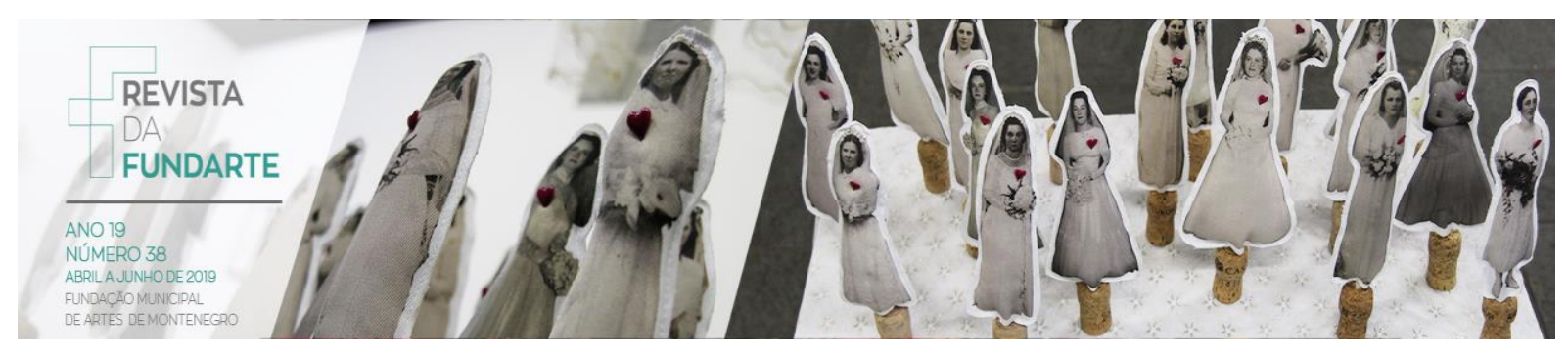

A maioria das brincadeiras desenvolvidas no cotidiano infantil pode ser classificada como folclóricas, pois são transmitidas de forma oral de uma geração à outra e por serem brincadeiras de aceitação coletiva que acontecem nas praças, nas ruas, nos parques, nos recreios. Estas brincadeiras folclóricas, em virtude de necessitarem da troca do conhecimento da prática de cada brincadeira, do ensinamento das regras entre os pares, incidem na oportunidade da criança desenvolver suas trocas afetivas, bem como seu desenvolvimento intelectual.

O processo de colonização deixou legados significativos, no que diz respeito ao folclore para a composição e continuidade das histórias dos povos, suas influências e heranças fazem parte do cotidiano dos sujeitos até a contemporaneidade. Dentre as influências e heranças oriundas dos colonizadores, estão os contos de fada, as lendas, a literatura oral, os quais fazem parte dos saberes e fazeres do folclore infantil, bem como as brincadeiras folclóricas.

Em virtude da expressiva diversidade cultural brasileira algumas brincadeiras sofrem variações de acordo com a região e a época em que são desenvolvidas, no entanto, nota-se que, de acordo com as descrições de cada brincadeira, a essência e o objetivo não se alteram. Grande parte das brincadeiras folclóricas envolvem disputas individuais ou em grupos, demarcando o cotidiano da criança.

Friedmann" afirma que "Brincar é fundamental na infância por ser uma das linguagens expressivas do ser humano. Proporciona a comunicação, a descoberta do mundo, a socialização e o desenvolvimento integral". Assim, brincar pode ser um momento significativo para criança, pode ser a ocasião de reconhecer o mundo do adulto, exercitar sua fantasia, imaginação e criatividade.

Segundo Inocente ([s.d.]), as brincadeiras podem ser classificadas em sensoriais, de azar, de inteligência, dramatizada, de habilidades e motoras. Além desta classificação exposta por Inocente ([s.d.]), as brincadeiras também são

\footnotetext{
5 Texto de Marina Azaredo. Disponível em: <http://educarparacrescer.abril.com.br/comportamento/brincadeiras-todas-idades-502871.shtml>. Acesso em: 12 de dez. 2013.
}

VIEIRA, Rejanete. Corpos brincantes: o folclore como estratégia de trabalho com crianças em situação de vulnerabilidade e risco social. Revista da FUNDARTE, Montenegro, p.12-32, ano 19, no 38, abril/junho de 2019.

Disponível em: http://.seer.fundarte.rs.gov.br/index.php/RevistadaFundarte/index> 28 de junho de 2019. 


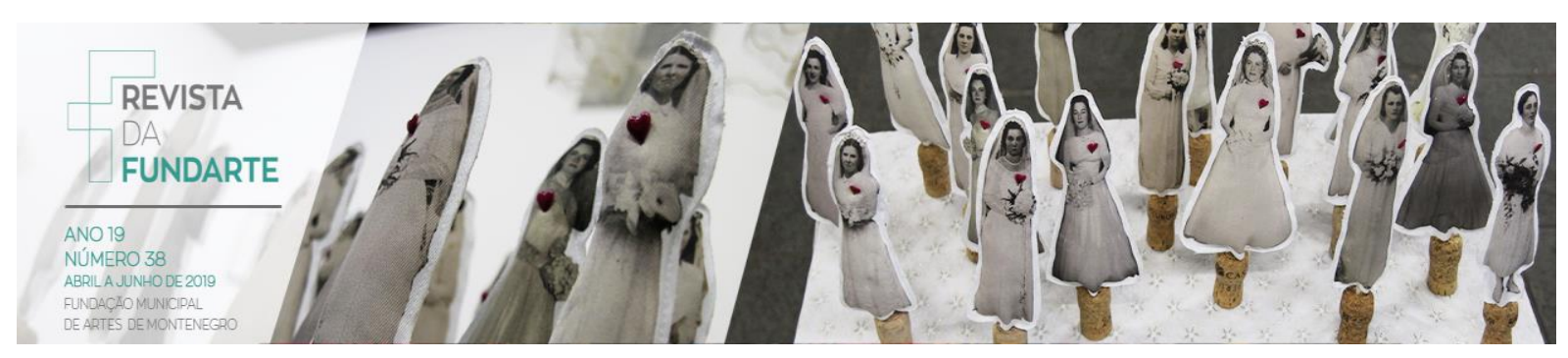

categorizadas como: brincadeiras de rua, brincadeiras de bola, brincadeiras de corrida, rodas cantadas, brincadeira de faz-de-conta (VASCONCELOS et al., 1999).

\section{Análise dos Dados e Discussão dos Resultados}

A análise dos dados foi realizada a partir de uma coleta feita na perspectiva do entrecruzamento entre objetivos e hipóteses.

\section{Sobre a condição de inibição/desinibição, disponibilidade corporal e pró-atividade dos alunos}

As três entrevistadas, (100\%) responderam que no começo das oficinas as crianças demonstraram certa inibição, apresentaram-se um pouco envergonhados, receosos. No entanto, com o decorrer apresentaram considerável disponibilidade e desembaraço.

A cerca deste questionamento as análises do contexto a partir dos vídeos, os quais podem ser acessados na íntegra no Apêndice B (pág. 83), demonstraram que as crianças se tornaram, ao longo do desenvolvimento das oficinas, com expressiva desinibição. Revelaram-se disponíveis corporalmente para o desenvolvimento das atividades, inclusive demonstrando relevante criatividade quando a proposta das brincadeiras se transformou na elaboração de uma composição coreográfica. Um exemplo desta situação ocorreu em uma das oficinas, onde um aluno sugeriu que a utilização de uma configuração fosse agregada a composição, ao ser questionado o motivo pelo qual poderíamos utilizá-la, prontamente respondeu que era uma parte de uma das brincadeiras feitas durante as aulas.

Esta disponibilidade corporal foi comprovada durante as observações. A cada oficina percebeu-se que o entendimento acerca do que seria uma coreografia, palavra complexa tanto na sua verbalização como na sua compreensão, considerando o contexto e a faixa etária, bem como na efetivação da composição da

VIEIRA, Rejanete. Corpos brincantes: o folclore como estratégia de trabalho com crianças em situação de vulnerabilidade e risco social. Revista da FUNDARTE, Montenegro, p.12-32, ano 19, no 38, abril/junho de 2019.

Disponível em: http://.seer.fundarte.rs.gov.br/index.php/RevistadaFundarte/index> 28 de junho de 2019. 


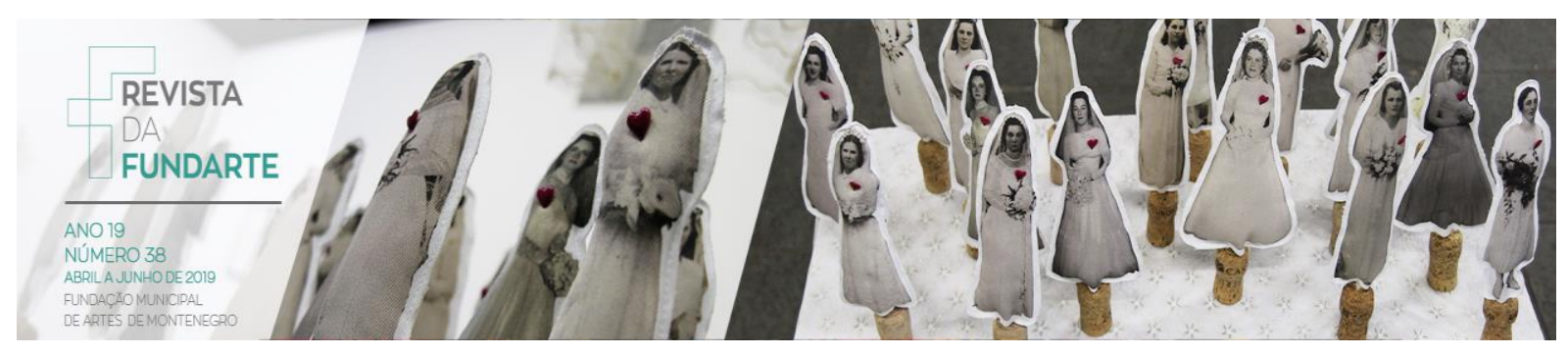

mesma. Os alunos comprovaram serem proativos, quando a coreografia começou a se delinear a partir das sugestões feitas com base nas experiências vivenciadas durante as Oficinas de Brincadeiras Folclóricas.

As explorações das possibilidades e as transformações ocorridas desde o início da proposta, até o momento em que os alunos não se comportavam nas oficinas como mais uma brincadeira, e sim atuavam como se estivessem em um ensaio da coreografia que estava se compondo, demonstrou que o trabalho desenvolvido com as Brincadeiras Folclóricas possibilitou a disponibilidade corporal necessária para a concepção dos fazeres da dança.

Marques (2010a, p. 156), neste sentido, defende que os elementos folclóricos a serem desenvolvidos na educação, devem ter como primeiro compromisso a fidelidade com a realidade do contexto, considerando as manifestações ali representadas. É indispensável se considerar que as relações traçadas entre uma manifestação e a construção do conhecimento em dança representam as experiências vividas pelos sujeitos, neste caso, as brincadeiras do cotidiano das crianças.

Como suporte para a apreensão das transformações das Brincadeiras Folclóricas em uma coreografia, cabe retomar Paulo Freire:

É preciso, sobretudo, e aí já vai um destes saberes indispensáveis, que o formando, desde o principio mesmo de sua experiência formadora, assumindo-se como sujeito também da produção do saber, se convença definitivamente de que ensinar não é transferir conhecimento, mas criar as possibilidades para a sua produção ou a sua construção. (FREIRE 1996, p.12).

As brincadeiras folclóricas podem ser transformadas pelas crianças, durante sua execução, diferentes modos de fazer podem modificar a atividade. Nesta perspectiva, as oficinas apresentaram-se como facilitadoras das transformações dos conhecimentos, proporcionando um fazer da dança.

VIEIRA, Rejanete. Corpos brincantes: o folclore como estratégia de trabalho com crianças em situação de vulnerabilidade e risco social. Revista da FUNDARTE, Montenegro, p.12-32, ano 19, no 38, abril/junho de 2019.

Disponível em: http://.seer.fundarte.rs.gov.br/index.php/RevistadaFundarte/index> 28 de junho de 2019. 


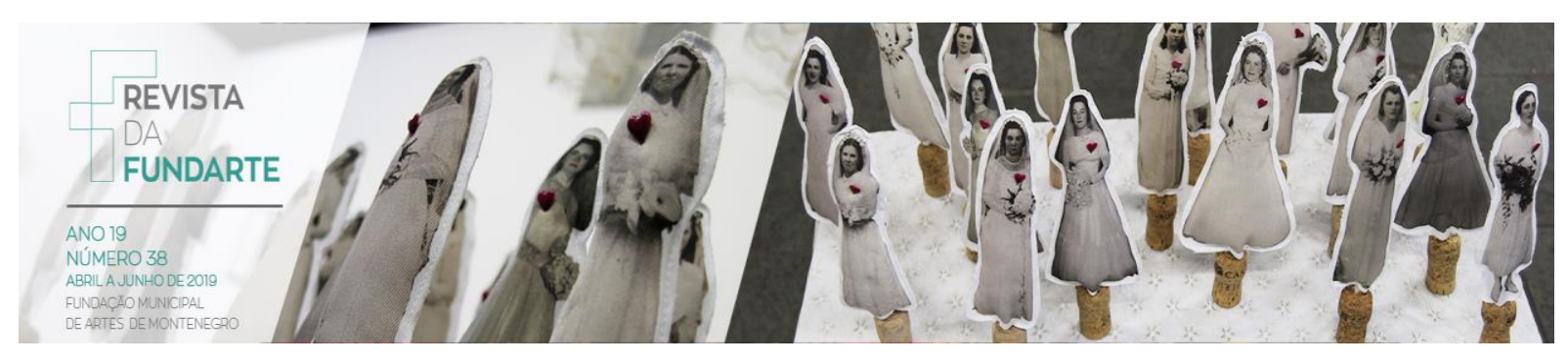

Sobre a modificação na relação das crianças com o ambiente

Dos sujeitos entrevistados, $(66,6 \%)$ responderam que, devido ao fato de as crianças morarem no mesmo local onde eram desenvolvidas as oficinas, pode ter dificultado a transformação da relação com os espaços. Por esse motivo não foram observadas mudanças nas relações com os mais diversos ambientes. Embora a percepção das entrevistadas tenha sido negativa ao questionamento proposto, a observação do contexto sugere o contrário. No princípio das oficinas, estas ocorriam na sala principal da casa, como já fora mencionado no capítulo da Metodologia, com a mudança para a sala denominada Sala de Recreação, onde algumas dificuldades iniciais merecem ressalva. Como o nome da sala já indica, os estímulos disponíveis são apresentados em quantidade significativa, pois nesta sala encontra-se uma televisão com um aparelho de reprodução de CD/DVD e uma estante com os mais variados exemplares de brinquedos.

Logo que as oficinas começaram a ocorrer nesta sala os alunos, ao serem chamados para o início das atividades, primeiro manuseavam os brinquedos, ligavam a televisão, verificavam se havia algum filme à disposição no aparelho, enfim dispersavam-se por alguns instantes, até que a oficina começasse a chamarIhes a atenção. Cabe salientar que, devido ao fato de estarem na casa deles, as regras a serem colocadas para o período de acontecimento da oficina eram limitadas, cujas regras se restringiam às questões de ordem comportamental, as quais foram listadas pelos próprios alunos.

No entanto, conforme as oficinas foram acontecendo e os alunos foram se apropriando dos conhecimentos em dança, a postura foi se transformando e, por conseguinte, a relação com o ambiente. Já não Ihes era necessário dispersar através dos estímulos disponíveis e já familiares a eles. Tornou-se interessante que a oficina começasse logo, para que pudessem ter novos aprendizados e assim, entrarem em contato com novos incentivos estabelecidos através das oficinas. Assim, a Sala de Recreação se transformou naqueles momentos da Sala de Aula de Dança.

VIEIRA, Rejanete. Corpos brincantes: o folclore como estratégia de trabalho com crianças em situação de vulnerabilidade e risco social. Revista da FUNDARTE, Montenegro, p.12-32, ano 19, no 38, abril/junho de 2019.

Disponível em: http://.seer.fundarte.rs.gov.br/index.php/RevistadaFundarte/index> 28 de junho de 2019. 


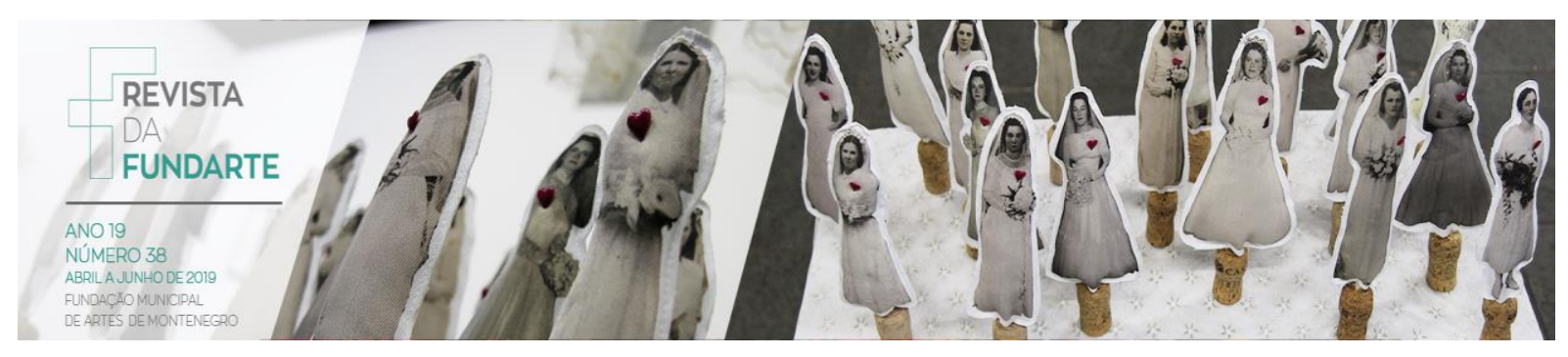

Sobre a sensação de pertencimento, por parte das crianças, a partir das histórias individuais e sociais

Nas respostas acerca da observação na modificação do comportamento das crianças, a partir da concepção do pertencimento por meio do trabalho com o folclore, através das brincadeiras folclóricas, houve um entendimento de que as crianças se tornaram mais participativas durante as atividades.

Nesta questão, a análise da observação na abordagem acerca das histórias individual e social tornou-se prejudicada. A maioria dos alunos parece negar sua história, embora houvesse atividades potencializadoras, que pudessem instigar relatos referentes às suas vivências anteriores, somente um aluno manifestou 0 desejo de discorrer sobre sua história antes do acolhimento.

Em contrapartida, quanto à sensação de pertencimento, durante 0 desenvolvimento das brincadeiras, destaca-se a analogia com as experiências vividas na escola, onde os alunos citavam exemplos de como ocorriam as brincadeiras durante o recreio. Exemplo significativo da percepção de experiências semelhantes, vividas em ambientes distintos: ao se dar início a composição coreográfica, o vocabulário durante as oficinas transformou-se, e palavras incomuns ao cotidiano dos alunos começaram a ser expostas, para um melhor entendimento das práticas da dança.

O ensaio faz parte do universo da dança. Quando a rotina de ensaios começou a fazer parte das oficinas, inclusive a própria denominação de ensaio atribuído à oficina, imediatamente relacionaram com as práticas realizadas na escola para apresentação de uma Quadrilha durante os festejos juninos. Nesta relação pode estar subentendido que, ensaiar nas oficinas e exercer a mesma prática na escola, é parte dos fazeres artísticos deste mundo e, embora não seja declarado com transparência, o pertencimento a este mesmo mundo esteja presente nas entrelinhas da comparação.

VIEIRA, Rejanete. Corpos brincantes: o folclore como estratégia de trabalho com crianças em situação de vulnerabilidade e risco social. Revista da FUNDARTE, Montenegro, p.12-32, ano 19, no 38, abril/junho de 2019.

Disponível em: http://.seer.fundarte.rs.gov.br/index.php/RevistadaFundarte/index> 28 de junho de 2019. 


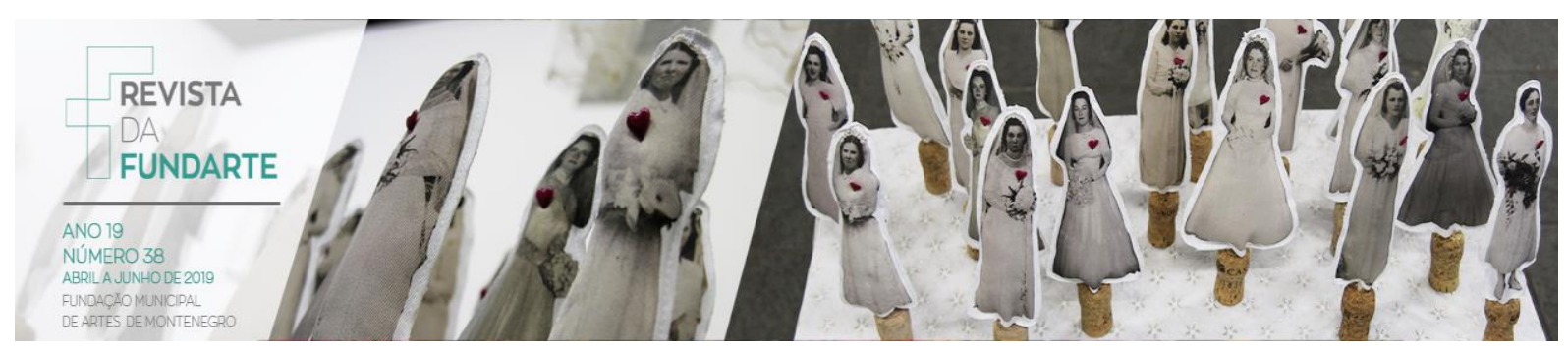

A análise dos dados discorreu sobre o cenário do qual fez parte as Oficinas de Brincadeiras Folclóricas, bem como envolveu informações acerca das possibilidades de abrangência do trabalho realizado a partir da temática do folclore. Tendo como ponto de vista a ideia de Fernandes (2003), de que a criança é um ser social, dentro de um mundo simbólico que necessita de meios para estabelecer significados, compreendê-los e, a partir daí ressignificá-los.

\section{Considerações Finais}

A ideia de corpo como uma instância de linguagem, que carrega consigo potência para expressar sentido, aparece na proposta de levar as brincadeiras folclóricas para um grupo de crianças moradoras do Abrigo Institucional Casa Carinho. Acredita-se que o trabalho, que é desenvolvido por meio das brincadeiras, tem um direcionamento que provoca um uso mais efetivo do corpo, uma vez que se propõe, por meio delas, um trabalho de folclore que seja dinâmico, na perspectiva da construção de uma corporeidade ativa.

Esta corporeidade ativa é entendida como possível veículo dos elementos propostos pelo folclore, dentro de suas diferentes formas de expressão, entendendose que o corpo representa o fio condutor na comunicação e transformação destas expressões.

Para esta ideia, confirmou-se que a possibilidade da corporeidade manifesta nas brincadeiras folclóricas propiciou a comunicação corporal entre as crianças, considerando que, durante o desenvolvimento das práticas, houve a transformação proposta através dos elementos disponíveis na brincadeira.

Ao constatar a carência de aportes que promovessem a esse grupo de crianças referências, no que diz respeito a elementos socializadores básicos da nossa sociedade, a brincadeira folclórica surgiu como possível meio na promoção dessa socialização. Nesse sentido, pôde-se constatar a pertinência do uso dessa linguagem folclórica a partir da análise dos dados, os quais possibilitaram verificar o potencial socializador das brincadeiras.

VIEIRA, Rejanete. Corpos brincantes: o folclore como estratégia de trabalho com crianças em situação de vulnerabilidade e risco social. Revista da FUNDARTE, Montenegro, p.12-32, ano 19, no 38, abril/junho de 2019.

Disponível em: http://.seer.fundarte.rs.gov.br/index.php/RevistadaFundarte/index> 28 de junho de 2019. 


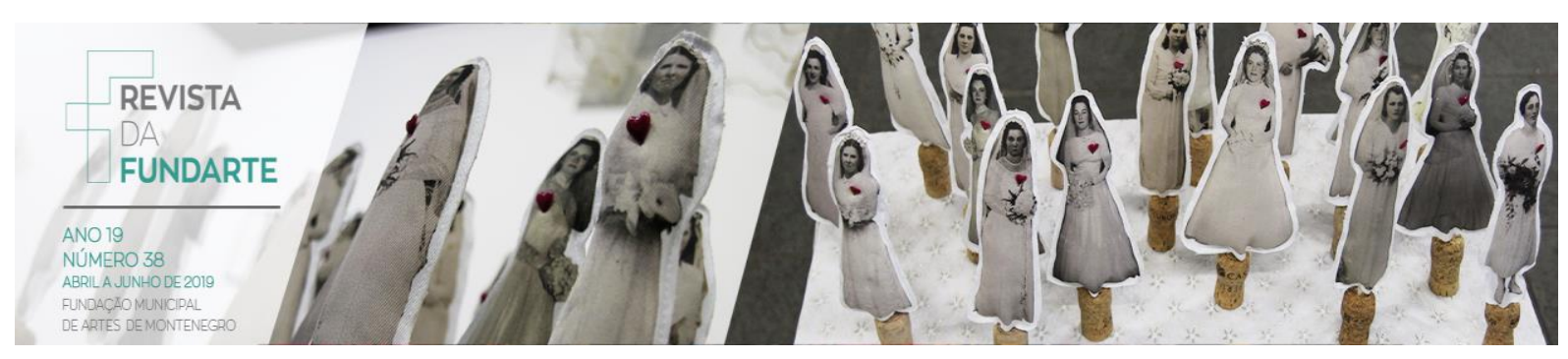

No decorrer das Oficinas de Folclore, se pode perceber as transformações na atitude corporal das crianças, demonstrando que haviam compreendido que esta rotina, que agora fazia parte de seu cotidiano, necessitava de uma disponibilidade de seus corpos, que provavelmente em outras atividades não ocorria a mesma exigência. Pode-se destacar a intencionalidade do toque, o qual tanto a brincadeira quanto o trabalho em dança, podem pressupor o que, no princípio das oficinas, quase não acontecia.

\section{Referências:}

CABRAL, Alfredo do Vale. Achegas ao estudo do folclore brasileiro. Rio de Janeiro: MEC-DAC-FUNARTE-Campanha de Defesa do Folclore Brasileiro, 1978. p. 21-30.

CÂMARA CASCUDO, Luís da. Dicionário do Folclore Brasileiro. 10 ed. Rio de Janeiro: Ediouro, (s/d).

CARVALHO NETO, Paulo de. Folclore e educação. Rio de Janeiro: Forense Universitária: Salamandra; São Paulo: Secretaria de Cultura do Estado de São Paulo, 1981. p. 5-10.

EDELWEISS, Frederico. Apontamentos de folclore. Salvador: Centro Editorial e Didático da Universidade Federal da Bahia, 1979. p. 17-23.

FERNANDES, Florestan. O folclore em questão. 2. ed. São Paulo: Martins Fontes, 2003.

FRADE, Cáscia. Folclore/cultura popular: aspectos de sua história. Disponível em: $<\mathrm{http}$ ://www.unicamp.br/folclore/Material/extra_aspectos.pdf>. Acesso em: $11 \mathrm{de}$ nov. 2013.

FREIRE, Paulo. Pedagogia da autonomia. Saberes necessários à prática educativa. São Paulo: Paz e Terra. 1996.

FRIEDMANN, Adriana. $A$ arte de brincar: brincadeiras e jogos tradicionais. Petrópolis: Vozes, 2004.

GENNEP, Arnold Von. Folklore. Salvador: Livraria Progresso, 1950. Tradução: Pinto de Aguiar. p. 31-47.

VIEIRA, Rejanete. Corpos brincantes: o folclore como estratégia de trabalho com crianças em situação de vulnerabilidade e risco social. Revista da FUNDARTE, Montenegro, p.12-32, ano 19, no 38, abril/junho de 2019.

Disponível em: http://.seer.fundarte.rs.gov.br/index.php/RevistadaFundarte/index> 28 de junho de 2019. 


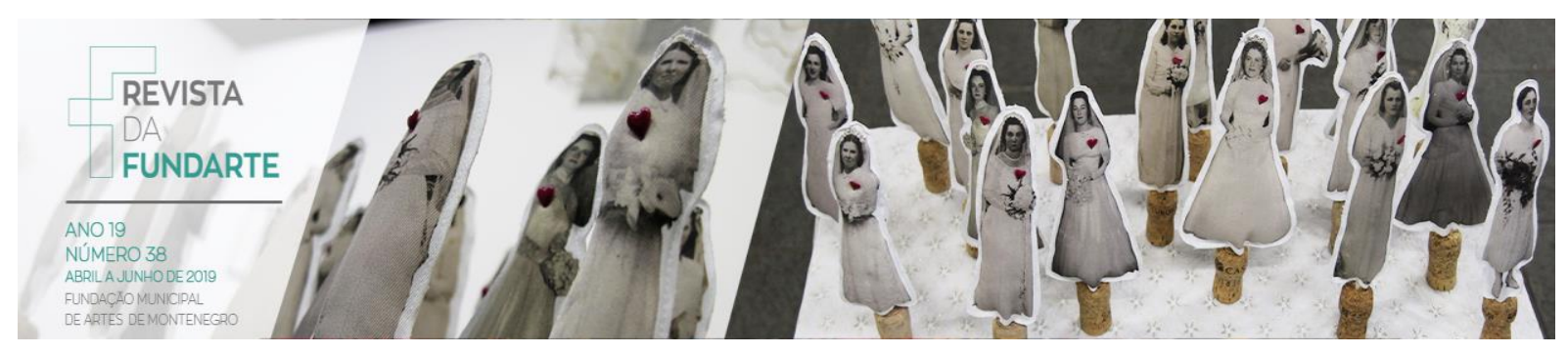

GONÇALVES, Maria Augusta Salin. Sentir, pensar e agir - Corporeidade e educação. Campinas: Papirus, 1994.

INOCENTE, Paulo. Folclore Infantil. (s/d): (s/l: CEITEC)

LE BRETON, David. Antropologia do corpo e modernidade. 2. ed. Petrópolis, RJ: Vozes, 2012.

MARQUES, Isabel A. Dançando na escola. 5. ed. São Paulo: Cortez, 2010a. p.155161.

Digitexto, 2010b.

Isabel A. Linguagem da dança: arte e ensino. 1. ed. São Paulo:

MIRANDA, Regina. Corpo-espaço: aspectos de uma geofilosofia do movimento. Rio de Janeiro: 7Letras, 2008.

PADOIN, Isabel Graciele; VIRGOLIN, Isadora Wayhs Cadore. A vulnerabilidade social como uma dificuldade a participação política. In: Seminário Interinstitucional de Ensino, Pesquisa e Extensão. XIII Mostra de Iniciação Científica. VIII Mostra de Extensão. UNICRUZ (2010). Disponível em: Acesso em: 13 de jan. 2013.

SAPIENZA, Graziela; PEDROMÔNICO, Márcia Regina Marcondes. Risco, proteção e resiliência no desenvolvimento da criança e do adolescente. Psicologia em Estudo, Maringá, v. 10, n. 2, p. 209-216, mai./ago. 2005. Disponível em: Acesso em 13 de jan. 2013.

VASCONCELOS, Cátia Barbosa de, et al. Brincadeira é coisa séria. 1999. Disciplina (Metodologia da Educação Física). Curso Pedagogia - Faculdade de Educação, Universidade Federal de Pelotas, Pelotas, 1999.

VIEIRA, Rejanete. Corpos brincantes: o folclore como estratégia de trabalho com crianças em situação de vulnerabilidade e risco social. Revista da FUNDARTE, Montenegro, p.12-32, ano 19, no 38, abril/junho de 2019.

Disponível em: http://.seer.fundarte.rs.gov.br/index.php/RevistadaFundarte/index> 28 de junho de 2019. 